\title{
Role of endoplasmic reticulum stress in lipopolysaccharide-inhibited mouse granulosa cell estradiol production
}

\author{
Lanjie $\mathrm{LEI}^{1,3)^{*}}$, Junbang $\mathrm{GE}^{2)^{*}}$, Hui ZHAO ${ }^{4)}$, Xiangguo WANG ${ }^{1,5)}$ and Lei YANG ${ }^{3)}$ \\ 1) Animal Science and Technology College, Beijing University of Agriculture, Beijing 102206, China \\ 2) Department of Rehabilitation Medicine, Tongji Hospital, Tongji Medical College, Huazhong University of Science and \\ Technology, Wuhan 430030, China \\ 3) Key Laboratory of System Bio-medicine of Jiangxi Province, Jiujiang University, Jiujiang, Jiangxi 332000, China \\ 4) Key Laboratory of Animal Biotechnology of the Ministry of Agriculture, Northwest A\&F University, Yangling 712100, China \\ ${ }^{5)}$ Beijing Key Laboratory of New Technique in Agricultural Application, Beijing University of Agriculture, Beijing 102206, \\ China
}

\begin{abstract}
The decrease in the level of estradiol $\left(\mathrm{E}_{2}\right)$ in granulosa cells caused by lipopolysaccharide (LPS) is one of the major causes of infertility underlying postpartum uterine infections; the precise molecular mechanism of which remains elusive. This study investigated the role of endoplasmic reticulum (ER) stress in LPS-induced $E_{2}$ decrease in mouse granulosa cells. Our results showed that LPS increased the pro-inflammatory cytokines [(interleukin (IL)-1 $\beta$, IL-6, IL-8, and tumor necrosis factor $(\mathrm{TNF})-\alpha)]$, activated ER stress marker protein expression [(glucose-regulated protein 78 (GRP78) and CCAAT/enhancerbinding protein homologous protein (CHOP)], and decreased cytochrome P450 family 19 subfamily A member 1 (Cyp19a1) expression and $\mathrm{E}_{2}$ production. Moreover, inhibition of ER stress by 4-phenylbutyrate (4-PBA) attenuated thapsigargin-(TG, ER stress agonist) or LPS-induced reduction of Cyp19a1 and $E_{2}$, pro-inflammatory cytokines expression (IL-1 $\beta$, IL-6, IL-8, and TNF- $\alpha$ ), and the expression of CHOP and GRP78. Additionally, inhibition of toll-like receptor 4 (TLR4) by resatorvid (TAK-242) reversed the inhibitory effects of LPS on Cyp19a1 expression and $\mathrm{E}_{2}$ production, activation of GRP78 and CHOP, and expression of IL-1 $\beta$, IL-6, IL-8, and TNF- $\alpha$. In summary, our study suggests that ER stress is involved in LPS-inhibited $\mathrm{E}_{2}$ production in mouse granulosa cells.
\end{abstract}

Key words: Endoplasmic reticulum stress, Estradiol, Granulosa cells, Lipopolysaccharide

(J. Reprod. Dev. 65: 459-465, 2019)

M icrobial infections of the uterus or mammary glands are major causes of severe disease and infertility in humans and domestic animals [1, 2], and cause post-partum uterine infections, that disrupt the endometrium, hypothalamic-pituitary axis, and ovarian endocrine functions [3, 4]. Lipopolysaccharide (LPS), derived from gram-negative bacteria such as Escherichia coli, is found in ovarian follicular fluid $[5,6]$ and influences the granulosa cell functions by activating immune signaling pathways. In the bovine granulosa cells, LPS binds to toll-like receptor 4 (TLR4) promotes nuclear factor- $\mathrm{kB}(\mathrm{NF}-\kappa \mathrm{B})$ translocation from the cytoplasm to the nucleus, and increases the levels of pro-inflammatory cytokines such as interleukin-1 $\beta$ (IL-1 $\beta$ ), IL-6, IL-8, and tumor necrosis factor (TNF)- $\alpha$ [7-10]. LPS also inhibits steroid production of bovine or porcine granulosa and theca cells $[5,11-13]$, decreases the expression of gonadotropin receptors and cytochrome P450 family 19 subfamily

Received: April 9, 2019

Accepted: July 24, 2019

Advanced Epub: August 11, 2019

(C)2019 by the Society for Reproduction and Development

Correspondences: X Wang (e-mail: xiangguo731@163.com) and L Yang

(e-mail: yangleigeili@163.com)

* L Lei and J Ge contributed equally to this work.

This is an open-access article distributed under the terms of the Creative Commons Attribution Non-Commercial No Derivatives (by-nc-nd) License. (CC-BY-NC-ND 4.0: https://creativecommons.org/licenses/by-nc-nd/4.0/)
A member 1 (Cyp19a1) in bovine granulosa and theca cells [11, 14, 15] and perturbs bovine oocyte meiotic progression in vitro [8]. In the mouse liver, pro-inflammatory cytokines, such as TNF- $\alpha$, IL-1 $\beta$, and IL-6, and LPS can induce endoplasmic reticulum (ER) stress and causes an acute phase response [16].

ER is essential for protein synthesis, folding, transport, and protein post-translational modifications [17, 18]. When the ER client protein load is in excess relative to the ER folding capacity, the accumulated proteins may cause ER stress [19, 20]. Under ER stress, ER-resident chaperone glucose-regulated protein 78 (GRP78) induced by unfolded proteins activates three ER membrane resident proteins: pancreatic ER kinase (PERK), inositol requiring enzyme 1 (IRE1), and activating transcription factor 6 (ATF6) [21]. Under these conditions, ER load is ameliorated by following three methods: (1) a reduction in the entry of newly synthesized proteins into the ER through attenuating protein translation; (2) an increase in the protein-folding capacity by up-regulating ER gene expression; (3) the degradation of misfolded and unfolded proteins through ER-associated degradation (ERAD) and lysosome-mediated autophagy [18, 22, 23]. ER stress occurs widely in several physiological and pathological processes, including development, cell apoptosis, autophagy, and metabolic diseases [18, 24]. The role of ER stress in immune response [25, 26], inflammation [25], and female reproduction [27-31] have also been reported previously. Moreover, some studies have reported that LPS induces inflammation by regulating ER stress in acute lung injury models 
[32] and liver ischemia-reperfusion injury [33].

As mentioned above, LPS inhibits steroid production induced by the immune response, which further impairs female reproduction [8, $10,14]$. Moreover, ER stress participates in LPS-induced immune responses and hormones secretion in male and female reproductive systems [27-30]. Additionally, ER stress can regulate inflammation in some pathological models [32, 33]. However, whether ER stress is involved in LPS-inhibited estradiol $\left(\mathrm{E}_{2}\right)$ production, and the relationships between immune responses and ER stress caused by LPS in mouse granulosa cells are unclear. In this study, we aim to define the role of ER stress in LPS-induced immune factors and $\mathrm{E}_{2}$ secretions in mouse granulosa cells.

\section{Materials and Methods}

\section{Animals and chemicals}

Immature female Kunming white mice (21-28 days old) were obtained from the Experimental Animal Center of Jiujiang University, China. All mice were fed chow and water daily and housed in a controlled temperature and humidity environment with a 12 -h lightdark cycle at $25^{\circ} \mathrm{C}$. All procedures were approved by the Committee for Ethical Animal Care and Experimentation of Jiujiang University, China [Approval No. SYXK(GAN)2017-0001].

All chemicals were obtained from Sigma-Aldrich (St. Louis, MO, USA) unless otherwise stated. LPS (E. coli (O55:B55)) was prepared as stock solutions in distilled phosphate buffer solution (PBS). ER stress inhibitor 4-phenylbutyrate (4-PBA), ER stress agonist thapsigargin (TG), and TLR4 inhibitor resatorvid (TAK-242) were dissolved in anhydrous dimethyl sulfoxide (DMSO) to prepare 7, 5, and $2.5 \mathrm{mM}$ stock solutions, respectively. All stock solutions were stored at $-20^{\circ} \mathrm{C}$. The final concentrations of 4-PBA, TG, and TAK-242 for culture were $700 \mathrm{nM}, 500 \mathrm{nM}$, and $250 \mathrm{nM}$, respectively. Prior to use, they were diluted with the culture medium, and the final concentration of DMSO was $0.1 \%$.

\section{Isolation, culture, and treatment of granulosa cells}

Mouse granulosa cells were collected and cultured based on previous reports with minor modifications $[34,35]$. The immature female mice were intraperitoneally injected with 8 IU pregnant mare serum gonadotropin (PMSG, Ningbo Sansheng, Ningbo, China) to facilitate granulosa cells proliferation. After $44 \mathrm{~h}$, the mice were sacrificed by decapitation, and their ovaries were quickly removed and placed in PBS containing $80 \mathrm{IU} / \mathrm{ml}$ penicillin and $100 \mathrm{mg} / \mathrm{ml}$ streptomycin. Granulosa cells were harvested by puncturing individual ovarian follicles with a 27 -gauge needle attached to a $1 \mathrm{ml}$ syringe, collected by centrifugation (1000 rpm, $5 \mathrm{~min}$ ) and cultured in a humidified incubator at $37^{\circ} \mathrm{C}$ with $5 \% \mathrm{CO}_{2}$ in Dulbecco's modified Eagle's medium/ Ham's F 12 nutrient medium (DMEM/F12, Hyclone, USA) containing $100 \mathrm{IU} / \mathrm{ml}$ penicillin, $100 \mu \mathrm{g} / \mathrm{ml}$ streptomycin, and $10 \%$ fetal bovine serum (FBS, Corning, Corning, NY, USA).

After $48 \mathrm{~h}$ of initial establishment, the cells were treated with $0.01-10 \mu \mathrm{g} / \mathrm{ml}$ LPS for $24 \mathrm{~h}$ to analyze pro-inflammatory cytokine expression (including IL-1 $\beta$, IL-6, IL-8, and TNF- $\alpha$ ), ER stress, and Cyp19a1 expression or for $48 \mathrm{~h}$ to detect $\mathrm{E}_{2}$ production. Meanwhile, an additional group of cells was exposed to $1 \mu \mathrm{g} / \mathrm{ml}$ LPS and 700 nM ER stress inhibitor 4-PBA or 250 nM TLR4 inhibitor TAK-242 for $24 \mathrm{~h}$ or $48 \mathrm{~h}$. To investigate whether the ER stress pathway is responsible for LPS-induced $\mathrm{E}_{2}$ reduction in mouse granulosa cells, the cells were also treated with $500 \mathrm{nM}$ TG with or without $700 \mathrm{nM}$ 4-PBA for $24 \mathrm{~h}$ or $48 \mathrm{~h}$. All experiments were performed in triplicate.

\section{Enzyme-linked immunosorbent assay}

Cells were seeded in a 24 -well plate at $1 \times 10^{5}$ cells/well. After culturing, the cells were counted, and the culture supernatant was centrifuged to remove debris. The concentration of IL-1 $\beta$ (cat. no. JYM0531Mo), IL-6 (cat. no. JYM0012Mo), IL-8 (cat. no. JYM0457Mo), and TNF- $\alpha$ (cat. no. JYM0218Mo) in the culture medium was analyzed at $24 \mathrm{~h}$ using commercial enzyme-linked immunosorbent assay kits (ELISA, Ji Yin Mei, Wuhan, China) according to the manufacturer's instructions. The concentration of E2 in the culture supernatant was measured at $48 \mathrm{~h}$ by an $\mathrm{E}_{2}$ ELISA kit (cat. no. JYM0379Mo; Ji Yin Mei), according to the manufacturer's instructions. The differences in intra-assay and inter-assay of all the ELISA kits are less than $9 \%$ and $15 \%$, respectively. The optical density at $450 \mathrm{~nm}$ of each well was determined using a microplate reader (Model 680; Bio-Rad Laboratories, Hercules, CA, USA).

\section{Western blot analysis}

Mouse granulosa cells were rapidly washed with ice-cold PBS. The lysate was separated from cellular debris by centrifugation at 13,000 $\mathrm{rpm}$ for $10 \mathrm{~min}$. After total protein was measured by a bicinchoninic acid (BCA) assay (Nanjing KeyGen, Nanjing, China), the samples were stored at $-80^{\circ} \mathrm{C}$ for subsequent use. Before electrophoresis, the samples were heated to $100^{\circ} \mathrm{C}$ for $5 \mathrm{~min}$, cooled on ice immediately, and then centrifuged at $12,000 \times g$ for $5 \mathrm{~min}$. Each sample was separated by $12 \%$ sodium dodecyl sulfate-polyacrylamide gel electrophoresis (SDS-PAGE) and electro-transferred onto a polyvinylidene difluoride (PVDF) membrane (Millipore, Boston, MA, USA). After incubation in blocking buffer for $1 \mathrm{~h}$ at $37^{\circ} \mathrm{C}$, the membrane was incubated with anti- $\beta$-actin (1:2000; cat. no. KM9001L, Tianjin Sanjian, Tianjin, China), anti-CHOP (1:1000; cat. no. ab10444, Abcam, Cambridge, UK), anti-GRP78 (1:1000; cat. no. ab32618, Abcam, Cambridge, UK), and anti-Cyp19a1 (1:500; cat. no. sc14245, Santa Cruz, CA, USA) overnight at $4{ }^{\circ} \mathrm{C}$. After washing, the membranes were incubated with secondary antibody conjugated to horseradish peroxidase at $37^{\circ} \mathrm{C}$ for $30 \mathrm{~min}$. Finally, immunoreactive bands were visualized using a Super Signal West Pico kit (Proteintech, Wuhan, China) by the Bio-Rad imaging system (Bio-Rad, CA, USA) according to the manufacturer's instructions. The protein band densities were semi-quantified by densitometric analysis using ImageJ software 1.48 (Bethesda, MD, USA).

\section{Statistical analysis}

Data were analyzed by one-way ANOVA, and the analysis was performed using SPSS software (Version 13.0; SPSS, Chicago, IL, USA) with Tukey's post hoc test. $\mathrm{P}<0.05$ was regarded as statistically significant. All data are represented as the mean \pm SEM of at least three separate experiments. 


\section{Results}

LPS induces pro-inflammatory cytokine expression in mouse granulosa cells

The results revealed that the concentrations of TNF- $\alpha$, IL- $1 \beta$, IL- 6 , and IL- 8 in culture supernatants were increased in a dose-dependent manner in response to LPS (Fig. 1).

\section{LPS inhibits $E_{2}$ production and Cyp19a1 protein expression}

To assess the effects of LPS on steroid hormone levels, we measured the concentrations of $E_{2}$ in the culture medium after treatment with
LPS for $24 \mathrm{~h}$. The results showed that LPS inhibited $\mathrm{E}_{2}$ production in a dose-dependent manner (Fig. 2A). Similar to $E_{2}$ production, LPS suppressed the expression of Cyp19a1 in mouse granulosa cells (Fig. 2B).

\section{LPS induces ER stress in mouse granulosa cells}

To assess the effects of LPS on ER stress, the expression levels of ER stress-related proteins were analyzed by western blotting. The results showed that LPS induced the expression of GRP78 and CHOP in a dose-dependent manner. Moreover, $0.01 \mu \mathrm{g} / \mathrm{ml} \mathrm{LPS}$ was sufficient to activate GRP78, but the lowest concentration of
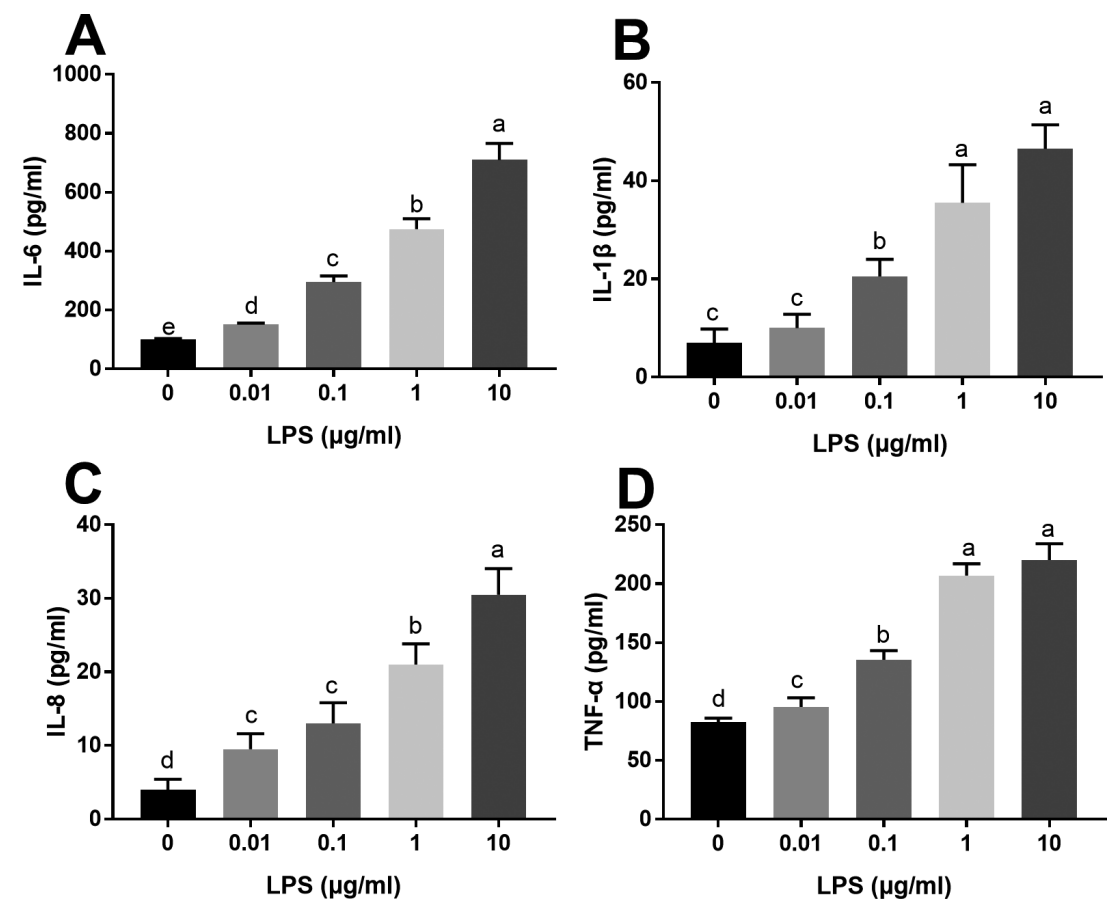

Fig. 1. Expression of pro-inflammatory cytokines (IL-6 (A), IL-1 $\beta$ (B), IL-8 (C), and TNF- $\alpha(\mathrm{D})$ ) in mouse granulosa cells after treatment with different concentrations $(0-10 \mu \mathrm{g} / \mathrm{ml})$ of LPS for $24 \mathrm{~h}$. Data are presented as the mean \pm SEM of three independent experiments. Bars with different letters are significantly different $(\mathrm{P}<0.05)$.
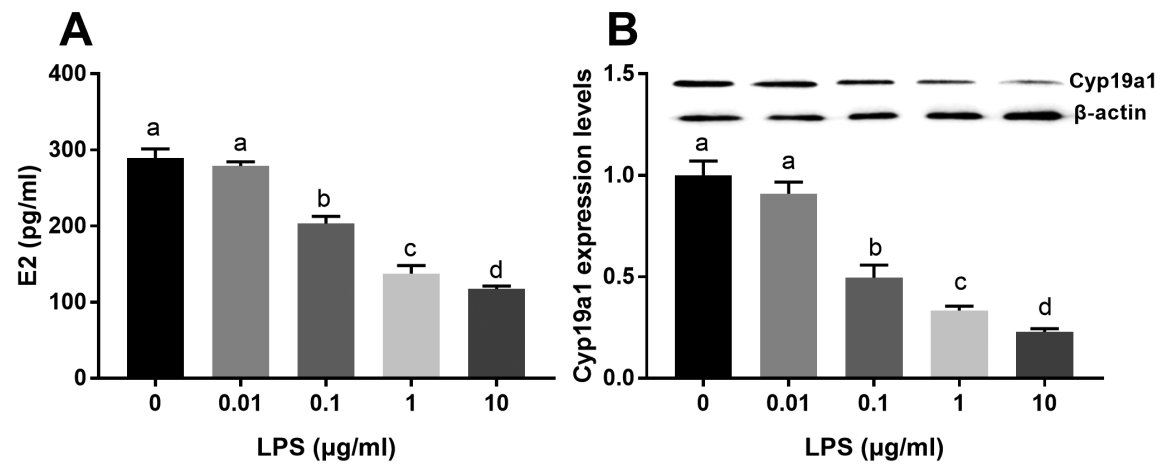

Fig. 2. The effects of LPS on $\mathrm{E}_{2}$ production (A) and Cyp19a1 expression (B). Data are presented as the mean \pm SEM of three independent experiments. Bars with different letters are significantly different $(\mathrm{P}<0.05)$. $\beta$-actin acted as an internal control. 

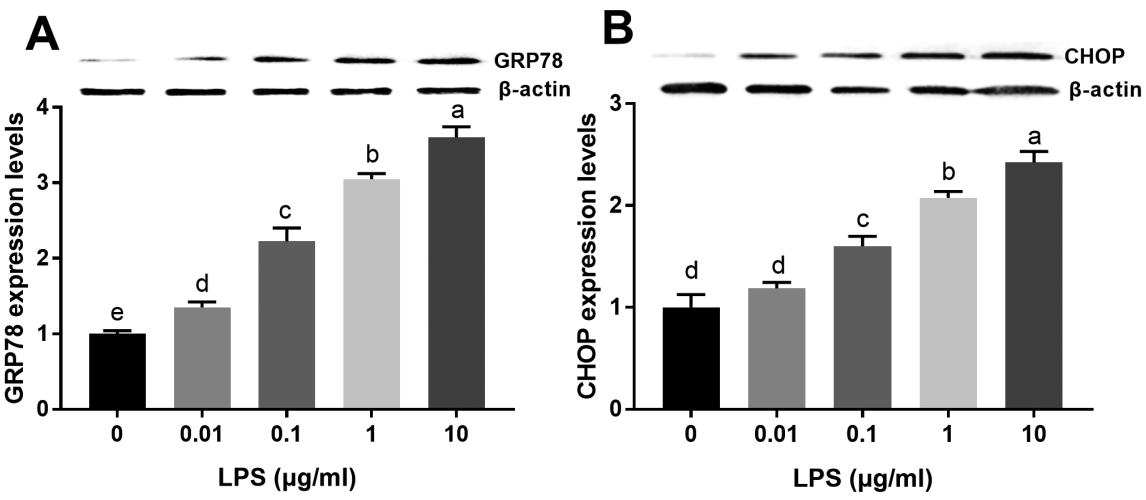

Fig. 3. The effects of LPS on the GRP78 (A) and CHOP (B) protein expression. Data are presented as the mean \pm SEM of three independent experiments. Bars with different letters are significantly different $(\mathrm{P}<0.05)$. $\beta$-actin acted as an internal control.

LPS required for the induction of CHOP expression was $0.1 \mu \mathrm{g} / \mathrm{ml}$ (Figs. 3A and 3B).

\section{ER stress is involved in the LPS-induced $E_{2}$ decrease}

After mouse granulosa cells were cultured and treated with 500 $\mathrm{nM}$ TG or $0.1 \mu \mathrm{g} / \mathrm{ml}$ LPS, ER stress-related markers (GRP78 and CHOP) were activated (Figs. 4A-4C), and $\mathrm{E}_{2}$ and Cyp19a1 were decreased (Figs. 4A, 4D, and 4E). Moreover, $700 \mathrm{nM}$ 4-PBA inhibited the TG- or LPS- induced GRP78 and CHOP expression (Figs. 4A, 4B, and 4C) and partly rescued the TG- or LPS -induced decrease of Cyp19a1 and $\mathrm{E}_{2}$ (Figs. 4A, 4D, and 4E). In addition, LPS and TG increased the expression levels of cytokine factors (IL-6, IL- $\beta$, IL-8, and TNF- $\alpha$ ) and 4-PBA treatment decreased the levels of cytokine factors caused by LPS or TG (Figs. 4F-I).

\section{TLR4 is involved in the LPS-induced $E_{2}$ decrease and ER stress}

LPS was added to the medium containing $250 \mathrm{nM}$ TLR4 inhibitor TAK-242, and the LPS-induced pro-inflammatory cytokines (IL-1 $\beta$, IL-6, IL-8, and TNF- $\alpha$ ) were decreased by the presence of TAK-242 after culture for $24 \mathrm{~h}$ (Figs. 5A-5D). Moreover, TAK-242 reduced the protein levels of GRP78 and CHOP (Figs. 5F and 5G); and the LPS-induced decreases in $\mathrm{E}_{2}$ and Cyp19a1 were partly inhibited by TAK-242 (Figs. 5H and 5I).

\section{Discussion}

Bacterial infections of the uterus or mammary glands perturb reduced ovarian follicle growth and functions, and these effects are mediated directly by bacterial LPS [12, 36-38]. Moreover, LPS activates the pro-inflammatory immune response through TLR4 signaling to decrease Cyp19a1 expression and $\mathrm{E}_{2}$ production [9, 39]. It is well known that pro-inflammatory cytokines disrupt steroidogenesis in granulosa cells [12, 40, 41]. However, in granulosa cells, a potential role of ER stress in impaired steroidogenesis in response to LPS has received little attention. In this study, we first examined the LPS on pro-inflammatory cytokine expression in mouse granulosa cells. Our study showed that LPS activated pro- inflammatory cytokines, including TNF- $\alpha$, IL-1 $\beta$, IL-6, and IL-8, which is in agreement with previous studies showing induction of pro-inflammatory cytokine expression by LPS in bovine granulosa cells $[8,9,39,42]$. Previous studies have demonstrated that LPS significantly decreases the Cyp19a1 [39] and $\mathrm{E}_{2}$ production $[9,39]$ in bovine. A similar decrease in Cyp19a1 expression and $\mathrm{E}_{2}$ production, upon treating mouse granulosa cells with LPS was observed in this study as well. However, a study from bovine granulosa cells reported that LPS did not affect the $\mathrm{E}_{2}$ production in granulosa cells isolated from small follicles, but down-regulated the aromatase expression in granulosa cells or large follicles [15].

Previous studies have reported that ER stress has broader physiological roles in the various reproductive processes of female mammals [18], including embryo implantation [43], preimplantation embryonic development [44], follicle atresia [28, 45], and hormone secretion $[35,43,46]$. Related studies confirmed that the long isoform of the ER stress signaling pathway protein CREBZF is closely related to murine implantation and can be up-regulated by $\mathrm{E}_{2}$ [43]. Another study reported that TLR4-mediated ER stress is involved in LPS induced mouse intestinal stem cell apoptosis [47]. Therefore, we hypothesized that ER stress signaling might be activated by LPS in mouse granulosa cells. To study the effects of LPS on ER stress, the ER stress marker molecules, GRP78 and CHOP, were examined after treatment with various concentrations of LPS. The GRP78 and CHOP were increased in a dose-dependent manner after induction by LPS at $24 \mathrm{~h}$. This result was similar to a previous study that LPS can induce ER stress in intestinal stem cells [47]. Moreover, some studies have reported that ER stress is related to hormone secretion $[35,43,46]$. Next, we assessed the involvement of ER stress in the LPS-induced $\mathrm{E}_{2}$ decrease. The results showed that LPS inhibited the expression of Cyp19a1 and $E_{2}$, and this effect was reversed by ER stress inhibitor 4-PBA, suggesting that the ER stress was involved in LPS-induced $\mathrm{E}_{2}$ down-regulation. There are three ER-localized protein sensors for ER stress: IRE1 $\alpha$, PERK, ATF6. Previous studies have reported that ATF6 is related to both the $E_{2}$ production [48] and the inflammatory response [33]. Therefore, we hypothesized that ATF6 might be responsible for the LPS-induced $\mathrm{E}_{2}$ decrease in the granulosa cells. However, further studies are also necessary 
A
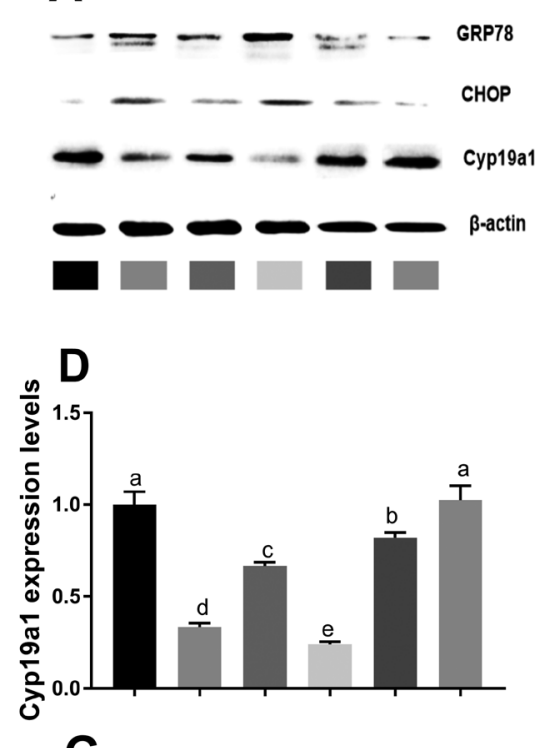

$\mathbf{G}$

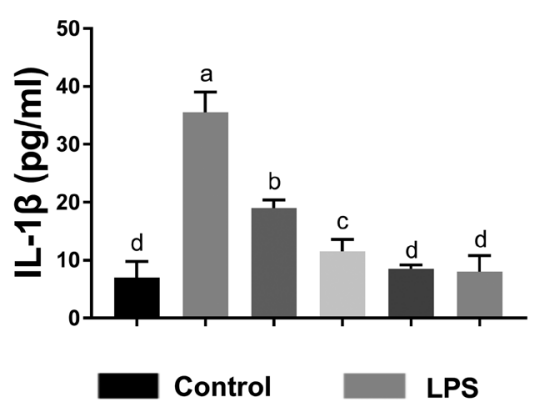

B
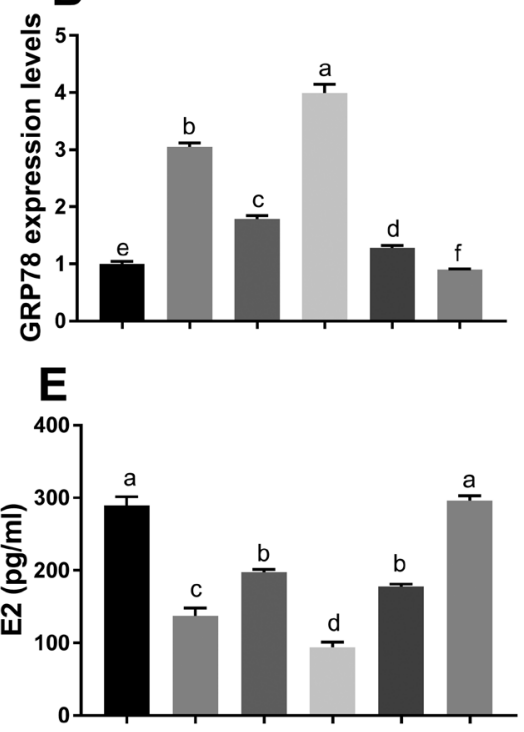

H

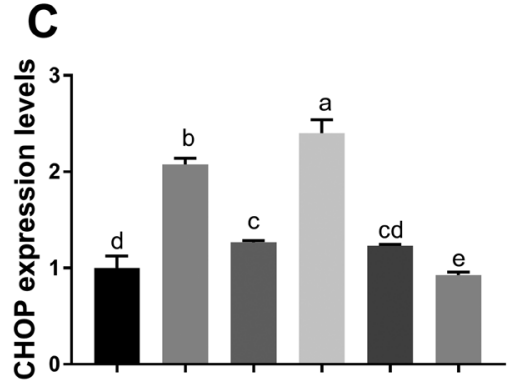

$\mathbf{F}$

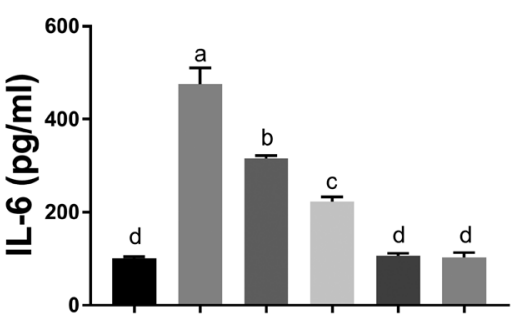

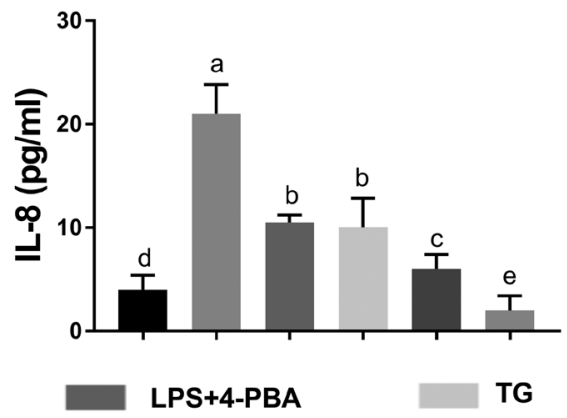

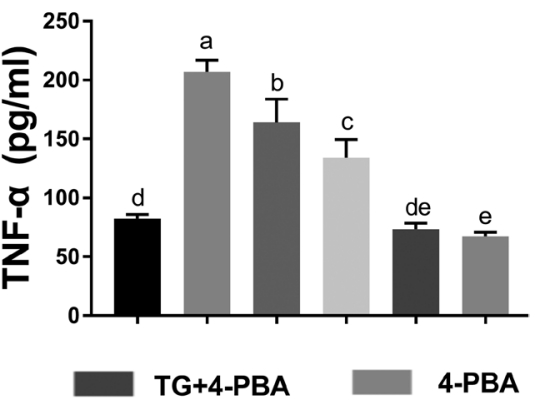

Fig. 4. Relationship between ER stress and LPS-induced $\mathrm{E}_{2}$ reduction. (A-D) The protein expression levels of GPR78, CHOP, and Cyp19a1 in different groups; (E) $\mathrm{E}_{2}$ levels of supernatant in different groups; (F-H) The expression of pro-inflammatory cytokines (IL-6 (F), IL-1 $1 \mathrm{G}$ ), IL-8 (H), and TNF- $\alpha(\mathrm{I})$ ) in different groups. Different colors are used to represent different groups, TG: Thapsigargin. Data are presented as the mean \pm SEM of three independent experiments. Bars with different letters are significantly different $(\mathrm{P}<0.05)$. $\beta$-actin acted as an internal control.

to determine to test this hypothesis. ER stress, induced by TG, also decreased Cyp19a1 expression and $\mathrm{E}_{2}$ production. Furthermore, LPS significantly increased the levels of cytokines (IL- 6 , IL- $\beta$, IL-8, and TNF- $\alpha$ ), and the increased expressions of cytokine were inhibited by 4-PBA. This result coincides with a previous report showing that LPS decreases the IL- $1 \beta$ level in CHOP-/-mice, indicating that suppression of ER stress inhibits inflammation. The related mechanism in CHOP-/-mice was the low expression of caspase-11 after LPS treatment [49].

Previous studies have reported LPS induces pro-inflammatory cytokines expression in granulosa cells through TLR4 [8, 50], and the inflammatory response is related to ER stress and an $\mathrm{E}_{2}$ decrease [25]. Therefore, we assumed that TLR4 might contribute to suppression of $\mathrm{E}_{2}$ production and ER stress in mouse granulosa cells caused by LPS. Our data demonstrated that LPS stimulated pro-inflammatory cytokines as well as expression of GRP78 and CHOP, and reduced $\mathrm{E}_{2}$. As expected, inhibition of TLR4 by TAK-242 significantly inhibited the LPS-induced inflammatory response,
ER stress, and $E_{2}$ reduction. These results supported the previous studies in which LPS bound to TLR4 and promoted the expression of pro-inflammatory cytokine expressions in bovine granulosa cells [7-10]. Subsequently, pro-inflammatory cytokines induced ER stress to decrease Cyp19a1 expression and E2 production. As our results showed, blocking TLR4 reduced ER stress, suggesting that the inflammatory response was one of the factors that decreased $\mathrm{E}_{2}$ production during LPS treatment. Conversely, inhibition of ER stress by 4-PBA attenuated pro-inflammatory cytokines expression, indicating that the inflammatory response and ER stresses interact with each other during the LPS-induced $\mathrm{E}_{2}$ decrease in mouse granulosa cells. The possible mechanism might be an inflammatory response mediated disruption of ER homeostasis, causing ER stress; the inhibition of the inflammatory response, therefore, suppresses ER stress during LPS treatment, and a persistent ER stress might cause cell dysfunctions that further induces the inflammatory response. Thus, inhibition of ER stress also inhibits the inflammatory response; however, the exact underlying mechanism between them requires further investigation. 


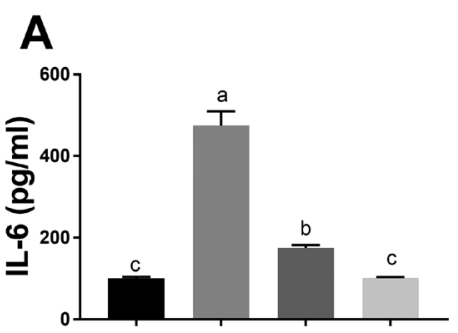

B

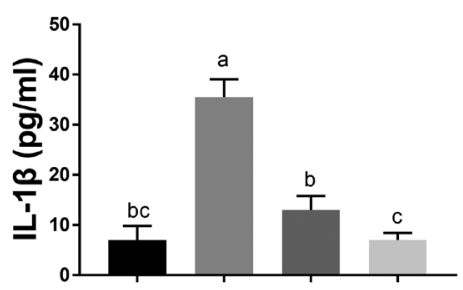

D
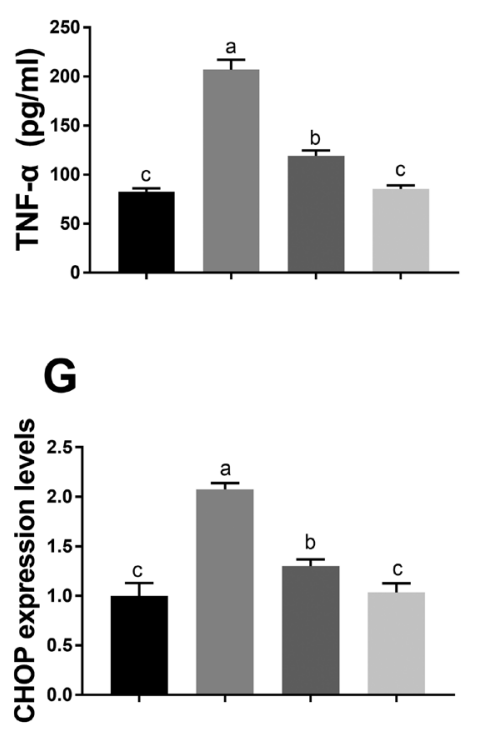

Control
E

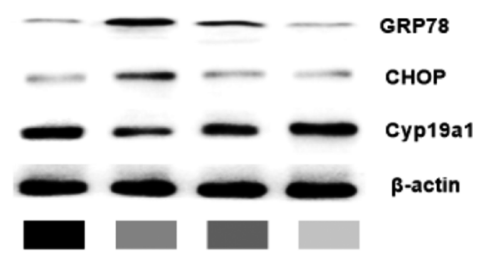

H

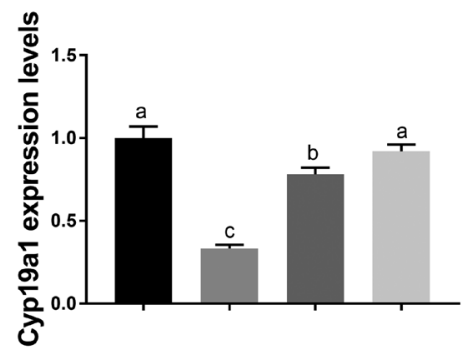

LPS
C

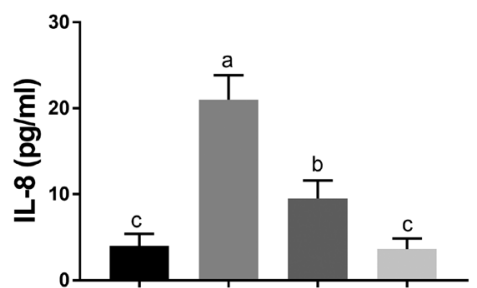

$F$

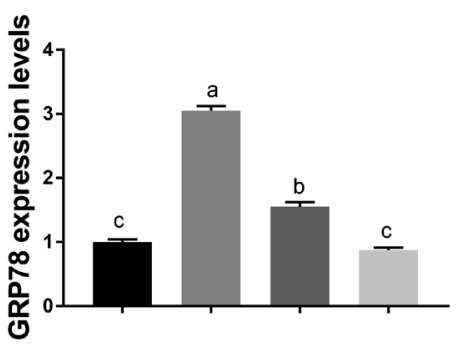

I

Fig. 5. TLR4 is involved in LPS-induced $E_{2}$ decrease and ER stress. (A-C) The concentration of IL-6, IL-1 $\beta$, IL- 8 , and TNF- $\alpha$ in the culture media at 24 $\mathrm{h} ;(\mathrm{E}-\mathrm{H})$ The protein expression levels of GPR78, CHOP, Cyp19a1; (I) $\mathrm{E}_{2}$ levels in the supernatant in different treatment groups. Different colors are used to represent different groups. Data are presented as the mean \pm SEM of three independent experiments. Bars with different letters are significantly different $(\mathrm{P}<0.05)$. $\beta$-actin acted as an internal control.

In overall, our study suggested that LPS treatment induces ER stress and an $\mathrm{E}_{2}$ reduction in mouse granulosa cells. Inhibiting the inflammatory response by TAK-242 reduced the activation of ER stress and rescued the decrease of $\mathrm{E}_{2}$. Conversely, inhibition of ER stress by 4-PBA also attenuated pro-inflammatory cytokines expression and the $\mathrm{E}_{2}$ decrease. Therefore, ER stress plays a vital role in the $\mathrm{E}_{2}$ reduction caused by LPS in murine granulosa cells, suggesting a cross-talk between the inflammatory response and ER stress during this process.

Conflict of Interest: The authors declare that they have no competing interests.

\section{Acknowledgments}

This study was funded by National Natural Science Foundation of China (Program NO. 31802263), The Project of Science and Technology of Jiangxi Provincial Education Department (Pro- gram No. GJJ170966), National key research plan "research on common diseases prevention and control technology of livestock and poultry" (Program NO. 2017YFD0502200), and Beijing dairy industry innovation team (Program NO. BAIC05-2017).

\section{References}

1. Sheldon IM, Noakes DE, Rycroft AN, Pfeiffer DU, Dobson H. Influence of uterine bacterial contamination after parturition on ovarian dominant follicle selection and follicle growth and function in cattle. Reproduction 2002; 123: 837-845. [Medline] [CrossRef]

2. Wira CR, Fahey JV, Sentman CL, Pioli PA, Shen L. Innate and adaptive immunity in female genital tract: cellular responses and interactions. Immunol Rev 2005; 206: 306-335. [Medline] [CrossRef]

3. Sheldon IM, Bromfield JJ. Innate immunity in the human endometrium and ovary. Am J Reprod Immunol 2011; 66(Suppl 1): 63-71. [Medline] [CrossRef]

4. Battaglia DF, Krasa HB, Padmanabhan V, Viguié C, Karsch FJ. Endocrine alterations that underlie endotoxin-induced disruption of the follicular phase in ewes. Biol Reprod 2000; 62: 45-53. [Medline] [CrossRef]

5. Magata F, Horiuchi M, Echizenya R, Miura R, Chiba S, Matsui M, Miyamoto A, Kobayashi Y, Shimizu T. Lipopolysaccharide in ovarian follicular fluid influences the steroid production in large follicles of dairy cows. Anim Reprod Sci 2014; 144: 6-13. 
[Medline] [CrossRef]

6. Pelzer ES, Allan JA, Cunningham K, Mengersen K, Allan JM, Launchbury T, Beagley K, Knox CL. Microbial colonization of follicular fluid: alterations in cytokine expression and adverse assisted reproduction technology outcomes. Hum Reprod 2011; 26: 1799-1812. [Medline] [CrossRef]

7. Onnureddy K, Ravinder, Onteru SK, Singh D. IGF-1 attenuates LPS induced proinflammatory cytokines expression in buffalo (Bubalus bubalis) granulosa cells. $\mathrm{Mol}$ Immunol 2015; 64: 136-143. [Medline] [CrossRef]

8. Bromfield JJ, Sheldon IM. Lipopolysaccharide initiates inflammation in bovine granulosa cells via the TLR4 pathway and perturbs oocyte meiotic progression in vitro. Endocrinology 2011; 152: 5029-5040. [Medline] [CrossRef]

9. Price JC, Bromfield JJ, Sheldon IM. Pathogen-associated molecular patterns initiate inflammation and perturb the endocrine function of bovine granulosa cells from ovarian dominant follicles via TLR2 and TLR4 pathways. Endocrinology 2013; 154: 3377-3386. [Medline] [CrossRef]

10. Price JC, Sheldon IM. Granulosa cells from emerged antral follicles of the bovine ovary initiate inflammation in response to bacterial pathogen-associated molecular patterns via Toll-like receptor pathways. Biol Reprod 2013; 89: 119. [Medline] [CrossRef]

11. Shimizu T, Miyauchi K, Shirasuna K, Bollwein H, Magata F, Murayama C, Miyamoto A. Effects of lipopolysaccharide (LPS) and peptidoglycan (PGN) on estradiol production in bovine granulosa cells from small and large follicles. Toxicol In Vitro 2012; 26: 1134-1142. [Medline] [CrossRef]

12. Williams EJ, Sibley K, Miller AN, Lane EA, Fishwick J, Nash DM, Herath S, England GC, Dobson H, Sheldon IM. The effect of Escherichia coli lipopolysaccharide and tumour necrosis factor alpha on ovarian function. Am J Reprod Immunol 2008; 60: 462-473. [Medline] [CrossRef]

13. Li H, Guo S, Cai L, Ma W, Shi Z. Lipopolysaccharide and heat stress impair the estradiol biosynthesis in granulosa cells via increase of HSP70 and inhibition of smad 3 phosphorylation and nuclear translocation. Cell Signal 2017; 30: 130-141. [Medline] [CrossRef]

14. Herath S, Williams EJ, Lilly ST, Gilbert RO, Dobson H, Bryant CE, Sheldon IM. Ovarian follicular cells have innate immune capabilities that modulate their endocrine function. Reproduction 2007; 134: 683-693. [Medline] [CrossRef]

15. Magata F, Horiuchi M, Miyamoto A, Shimizu T. Lipopolysaccharide (LPS) inhibits steroid production in theca cells of bovine follicles in vitro: distinct effect of LPS on theca cell function in pre- and post-selection follicles. J Reprod Dev 2014; 60: 280-287. [Medline] [CrossRef]

16. Zhang K, Kaufman RJ. From endoplasmic-reticulum stress to the inflammatory response. Nature 2008; 454: 455-462. [Medline] [CrossRef]

17. Pluquet O, Pourtier A, Abbadie C. The unfolded protein response and cellular senescence. A review in the theme: cellular mechanisms of endoplasmic reticulum stress signaling in health and disease. Am J Physiol Cell Physiol 2015; 308: C415-C425. [Medline] [CrossRef]

18. Yang Y, Pei X, Jin Y, Wang Y, Zhang C. The roles of endoplasmic reticulum stress response in female mammalian reproduction. Cell Tissue Res 2016; 363: 589-597. [Medline] [CrossRef]

19. Rasheva VI, Domingos PM. Cellular responses to endoplasmic reticulum stress and apoptosis. Apoptosis 2009; 14: 996-1007. [Medline] [CrossRef]

20. Guan G, Lei L, Lv Q, Gong Y, Yang L. Curcumin attenuates palmitic acid-induced cell apoptosis by inhibiting endoplasmic reticulum stress in $\mathrm{H} 9 \mathrm{C} 2$ cardiomyocytes. Hum Exp Toxicol 2019; 38: 655-664. [Medline] [CrossRef]

21. Yang L, Guan G, Lei L, Lv Q, Liu S, Zhan X, Jiang Z, Gu X. Palmitic acid induces human osteoblast-like Saos-2 cell apoptosis via endoplasmic reticulum stress and autophagy. Cell Stress Chaperones 2018; 23: 1283-1294. [Medline] [CrossRef]

22. Ellgaard L, Helenius A. Quality control in the endoplasmic reticulum. Nat Rev Mol Cell Biol 2003; 4: 181-191. [Medline] [CrossRef]

23. Yang Y, Cheung HH, Tu J, Miu KK, Chan WY. New insights into the unfolded protein response in stem cells. Oncotarget 2016; 7: 54010-54027. [Medline]

24. Yang L, Guan G, Lei L, Liu J, Cao L, Wang X. Oxidative and endoplasmic reticulum stresses are involved in palmitic acid-induced H9c2 cell apoptosis. Biosci Rep 2019; 39: 5. [Medline] [CrossRef]

25. Hasnain SZ, Lourie R, Das I, Chen AC, McGuckin MA. The interplay between endoplasmic reticulum stress and inflammation. Immunol Cell Biol 2012; 90: 260-270. [Medline] [CrossRef]

26. Todd DJ, Lee A-H, Glimcher LH. The endoplasmic reticulum stress response in immunity and autoimmunity. Nat Rev Immunol 2008; 8: 663-674. [Medline] [CrossRef]

27. Iwawaki T, Akai R, Yamanaka S, Kohno K. Function of IRE1 alpha in the placenta is essential for placental development and embryonic viability. Proc Natl Acad Sci USA 2009; 106: 16657-16662. [Medline] [CrossRef]

28. Lin P, Yang Y, Li X, Chen F, Cui C, Hu L, Li Q, Liu W, Jin Y. Endoplasmic reticulum stress is involved in granulosa cell apoptosis during follicular atresia in goat ovaries. Mol Reprod Dev 2012; 79: 423-432. [Medline] [CrossRef]

29. Lin P, Jin Y, Lan X, Yang Y, Chen F, Wang N, Li X, Sun Y, Wang A. GRP78 expres- sion and regulation in the mouse uterus during embryo implantation. J Mol Histol 2014; 45: 259-268. [Medline] [CrossRef]

30. Park H-J, Park S-J, Koo D-B, Lee S-R, Kong I-K, Ryoo J-W, Park Y-I, Chang K-T, Lee D-S. Progesterone production is affected by unfolded protein response (UPR) signaling during the luteal phase in mice. Life Sci 2014; 113: 60-67. [Medline] [CrossRef]

31. Yang Y, Sun M, Shan Y, Zheng X, Ma H, Ma W, Wang Z, Pei X, Wang Y. Endoplasmic reticulum stress-mediated apoptotic pathway is involved in corpus luteum regression in rats. Reprod Sci 2015; 22: 572-584. [Medline] [CrossRef]

32. Zeng M, Sang W, Chen S, Chen R, Zhang H, Xue F, Li Z, Liu Y, Gong Y, Zhang H, Kong X. 4-PBA inhibits LPS-induced inflammation through regulating ER stress and autophagy in acute lung injury models. Toxicol Lett 2017; 271: 26-37. [Medline] [CrossRef]

33. Rao J, Yue S, Fu Y, Zhu J, Wang X, Busuttil RW, Kupiec-Weglinski JW, Lu L, Zha Y. ATF6 mediates a pro-inflammatory synergy between ER stress and TLR activation in the pathogenesis of liver ischemia-reperfusion injury. Am J Transplant 2014; 14: 1552-1561. [Medline] [CrossRef]

34. Lei L, Han F, Cui Q, Liao W, Liu H, Guan G, Yang L. IRS2 depletion inhibits cell proliferation and decreases hormone secretion in mouse granulosa cells. J Reprod Dev 2018; 64: 409-416. [Medline] [CrossRef]

35. Chen Z, Lei L, Wen D, Yang L. Melatonin attenuates palmitic acid-induced mouse granulosa cells apoptosis via endoplasmic reticulum stress. J Ovarian Res 2019; 12: 43. [Medline] [CrossRef]

36. Li L, Tang J, Sun Y, Wu J, Yu P, Wang G. Upregulation of HO-1 attenuates LPSstimulated proinflammatory responses through downregulation of $\mathrm{p} 38$ signaling pathways in rat ovary. Inflammation 2015; 38: 1085-1092. [Medline] [CrossRef]

37. MacKenzie S, Montserrat N, Mas M, Acerete L, Tort L, Krasnov A, Goetz FW, Planas JV. Bacterial lipopolysaccharide induces apoptosis in the trout ovary. Reprod Biol Endocrinol 2006; 4: 46. [Medline] [CrossRef]

38. Sheldon IM, Cronin J, Goetze L, Donofrio G, Schuberth H-J. Defining postpartum uterine disease and the mechanisms of infection and immunity in the female reproductive tract in cattle. Biol Reprod 2009; 81: 1025-1032. [Medline] [CrossRef]

39. Mehta A, Ravinder, Onteru SK, Singh D. HDAC inhibitor prevents LPS mediated inhibition of CYP19A1 expression and 17ß-estradiol production in granulosa cells. Mol Cell Endocrinol 2015; 414: 73-81. [Medline] [CrossRef]

40. Sakumoto R, Berisha B, Kawate N, Schams D, Okuda K. Tumor necrosis factor- $\alpha$ and its receptor in bovine corpus luteum throughout the estrous cycle. Biol Reprod 2000; 62: 192-199. [Medline] [CrossRef]

41. Spicer LJ. Tumor necrosis factor- $\alpha(\mathrm{TNF}-\alpha)$ inhibits steroidogenesis of bovine ovarian granulosa and thecal cells in vitro. Involvement of TNF- $\alpha$ receptors. Endocrine 1998; 8 109-115. [Medline] [CrossRef]

42. Price JC, Cronin J, Sheldon IM. Toll-like receptor expression and function in the COV434 granulosa cell line. Am J Reprod Immunol 2012; 68: 205-217. [Medline] [CrossRef]

43. Lin $\mathbf{P}$, Chen F, Wang N, Wang X, Li X, Zhou J, Jin Y, Wang A. CREBZF expression and hormonal regulation in the mouse uterus. Reprod Biol Endocrinol 2013; 11: 110 [Medline] [CrossRef]

44. Basar M, Bozkurt I, Guzeloglu-Kayisli O, Sozen B, Tekmen I, Schatz F, Arici A, Lockwood CJ, Kayisli UA. Unfolded protein response prevents blastocyst formation during preimplantation embryo development in vitro. Fertil Steril 2014; 102: 1777-1784. [Medline] [CrossRef]

45. Kogure K, Nakamura K, Ikeda S, Kitahara Y, Nishimura T, Iwamune M, Minegish T. Glucose-regulated protein, 78-kilodalton is a modulator of luteinizing hormone receptor expression in luteinizing granulosa cells in rats. Biol Reprod 2013; 88: 8-21. [Medline] [CrossRef]

46. Lin $\mathbf{P}$, Chen $\mathbf{F}$, Sun J, Zhou J, Wang X, Wang N, Li X, Zhang Z, Wang A, Jin Y Mycotoxin zearalenone induces apoptosis in mouse Leydig cells via an endoplasmic reticulum stress-dependent signalling pathway. Reprod Toxicol 2015; 52: 71-77. [Medline] [CrossRef]

47. Afrazi A, Branca MF, Sodhi CP, Good M, Yamaguchi Y, Egan CE, Lu P, Jia H, Shaffiey S, Lin J, Ma C, Vincent G, Prindle T Jr, Weyandt S, Neal MD, Ozolek JA, Wiersch J, Tschurtschenthaler M, Shiota C, Gittes GK, Billiar TR, Mollen K, Kaser A, Blumberg R, Hackam DJ. Toll-like receptor 4-mediated endoplasmic reticulum stress in intestinal crypts induces necrotizing enterocolitis. J Biol Chem 2014; 289: 9584-9599. [Medline] [CrossRef]

48. Xiong Y, Chen H, Lin P, Wang A, Wang L, Jin Y. ATF6 knockdown decreases apoptosis, arrests the $\mathrm{S}$ phase of the cell cycle, and increases steroid hormone production in mouse granulosa cells. Am J Physiol Cell Physiol 2017; 312: C341-C353. [Medline] [CrossRef]

49. Endo M, Mori M, Akira S, Gotoh T. C/EBP homologous protein (CHOP) is crucial for the induction of caspase-11 and the pathogenesis of lipopolysaccharide-induced inflammation. J Immunol 2006; 176: 6245-6253. [Medline] [CrossRef]

50. Takeuchi O, Akira S. Pattern recognition receptors and inflammation. Cell 2010; 140 805-820. [Medline] [CrossRef] 